\title{
Taidekasvatus - mahdollisuus laadullisten arvojen sisäistämiseen
}

Taidekasvatuksesta puhutaan kuin uskonnosta — ihmeitä tekevä voima on käden ulottuvilla mahdollisuutena ja alati vain mahdollisuutena. Keskiaikaisessa reliefissä kuvataan syntiinlankeemusta : Vasemmasta ylänurkasta tulee esiin Isä Jumalan syyttävä sormi osoittaen Aatamia, joka nöyristellen osoittaa Eevaa - varsinaista syyllistä. Epäoikeudenmukaisen tuomion kohteeksi joutunut Eeva kohdistaa sormensa käärmeeseen. Käärme ei osoita ketään, vaan luikertaa sormettomana tiehensä mokomasta paratiisista.

Mitä tehtäviä taidekasvatukselle on ajateltu, kun mahdollisuus kerran koittaa? 'Se on rentouttavaa, itseluottamusta palauttavaa runsaan uuden tiedon lomassa'. Jotain tuontapaista tuon tuosta tarjoillaan. Taidekasvattajana en näe ensisijaiseksi tehtäväkseni toimia taideparsijana. Yhden koon sukkia tuotetaan nykyään nopeasti ja niin halvalla, että koko taideparsijoiden ammattikunta on kadonnut. - Mihin muuten perustuu käsitys taidekasvatuksen rentouttavasta vaikutuksesta? Käsitelläänkö saman otsakkeen alla tavoitteiltaan väljää harrastamista ja kasvatus- ja koulutussisällön omaavaa opetustoimintaa?

Taidekasvatusta toteutetaan aivan saman koulutuskäytännön ilmapiirissä kuin muutakin koulutusta. Mihin perustuvat ajatukset taidekasvatuksen toisenlaisesta olemuksesta? - Pelkkää tekopyhää synnintuntoa ilman' katumuksen ajatustakaan. Taidekasvatuksen hyvät puolet ovat tiedossa. Kysymys on koko koulutuskäyttäytymisestä. Taidekasvatus saa juuri sellaisen sisällön kuin kulttuurin hahmo sille mahdollistaa. Ei taiteella ole mitään teoreettista vaikutusta, vaan juuri sen käytännön sallima vaikutus, joka heijastuu kaikesta muustakin koulutuksesta ja kasvatuksesta.
Koulutuskäytäntö suosii lähitavoitteita, nopeutta ja kapea-alaisuutta. Laadullisten vaatimusten sietoraja alenee. Tiedon ja kokemuksen irrallisuus horjuttaa kykyä arvioida ilmiöiden merkityksiä omien saavutustenkin. Arviointia kuitenkin halutaan. Ulkopuoliset arvioijat saavat lisääntyvässä määrin virallistetun aseman. Vastuu omasta, pienestäkin tekemisestä siirtyy koneistoon. Sopii miettiä vaikkapa nuorukaisen taidepolitiikan osalta: onko se tavoitteidensa mukaisesti edistänyt taiteen sisällöistä kehittymistä ja välittymistä — onko se kehitellyt määrällisyyteen perustuvia luokitteluja jonotusjärjestelmiä?

Taide ja taidekasvatus menettävät oleellisimman osan sisällöstään jos laadullisuuteen perustuvista arvoista niiden toimintapiirissä tingitään. Koulutuskäytäntö on laajalti hyväksynyt tilanteen, jossa tieto tiedon olemassaolosta riittää. Tiedon siirrosta on tullut formaalista valmentautumista siltä varalta, että joskus pitäisi tietää jotain. Kasvatustilanteen todellisuudesta vieraannutaan - yhä useammat oppilaat eivät tiedä opettajansa nimeä.

Opetusalalla palkkioperusteissa erotellaan luento-opetus henkilökohtaisen työskentelyn ohjauksesta siten, että luennointi palkitaan runsaammin. Niinkin muodollinen asia kuin palkkioperuste on ohjaamassa opetustapahtumia. Luennoiva opetus taidekasvatuksessa on lisääntynyt. Opiskelijat osaavat odottaa ja saavat yhä enemmän monisteita - tietopaaleja työnnetään pohjattomien pötsien märehdittäviksi. Taidekasvatuksen olemukseen kuuluu tiedon omaksuminen henkilökohtaisen kokemuksen avulla. Taidekasvatus ei ole moraalioppia, jossa hyvä opitaan erottamaan pahasta tuntemattomia ilmiöitä vannoen. Taidekasvatuksessa henkilökohtainen kokemus vie erottelukyvyn 
muutokset osaksi persoonallisuutta antaen arvostuksille sisäistetyn olemuksen. - En väitä, että siitä seuraisi pelkkää hyvää. Tinkimällä henkilökohtaisesta kokemuksesta tiedon välittäjänä taidekasvatus siirtyy sivuraiteelle.

Taidekasvatustapahtuma edellyttää:

— pitkäjännitteisyyttä

— intensiivisyyttä

- vallankumouksellista mieltä

Taidekasvatukseen liittyvät työmenetelmät sinänsä ovat hitaita ja tiettyä järjestystä edellyttäviä. Spontaanien tunteiden konkretisointi esim. etsaten vie aikaa useita tunteja. Kuitenkin myös etsaten on ilmaistu spontaaneja tunteita. Kokemuksella ja sen kuvallisella ilmaisulla on oma itsenäinen muotonsa. Kulloinkin parhaiten kokemusta vastaavan muodon etsintä on laajalle aikaisempiin kokemus, muisti- ja mielikuviin tunkeutuva prosessi. Monien mahdollisuuksien läpi tunkeutuessaan ajatuksen tulee säilyttää oleellisin — kuvattava kokemus. Oikeiden vastausten ja kysymysten esiintuloa on maltettava etsiä - myös ohjaajan.

Kuvallisessa ilmaisussa löytäminen ja etsiminen ovat luonnollisessa ja pakottomassa vuorovaikutussuhteessa. Kuvallisen ilmaisun merkittävä välillinen vaikutus saattaa sisältyä juuri tähän löytämisen ja etsimisen jatkuvaan vuorovaikutussuhteeseen - palautuu kyky oppia opittavaksi.

Kuvallisen ilmaisun lainalaisuudet ovat kietoutuneet monimutkaiseen vuorovaikutussuhteeseen. Vuorovaikutuksen tekee erityisen monimutkaiseksi se, että lopullisessa ilmaisullisessa muodossa kaikki tapahtumat ovat vaikuttamassa simultaanisesti, samanaikaisesti. Musiikissa aika on ennakoitavissa - tapahtumat järjestyvät aikatilaan. Simultaanisuus vaikuttaa kuvallisessa ilmaisussa kaiken aikaa. Jokainen ratkaisu muuttaa välittömästi aikaisemmin tehtyjen ratkaisujen luonnetta. Ennakoiva valinta voi olla vain viitteellinen, panos peliin, jossa häviö ja voitto ovat yhtä mahdollisia.
Toisaalta kuvallinen ilmaisu tapahtuu konkreettisella, nähtävällä materiaalilla. Tietokoneen viileydellä välittyy tekijälle viesti: aloita alusta, jatka. Viestin noudattaminen, siitä kieltäytyminen on oleellinen osa kokemuksen ja sen ilmaisemisen välistä vuorovaikutusta. - Sikäli kuin kyse on vain kokemuksen ilmaisemisesta.

Puhtaimmillaan kuvallisen ilmaisun valintoja säätelevät laadulliset ominaisuudet. Punaisella maalataan siksi, että sen sävyarvo omaa tiettyä ilmaisullista ominaisuutta. Ei punaista voi valita sen vuoksi, että itse tai hyvät toverit pitävät punaisesta - edes siksi, että sitä on runsaasti. Ilmaisullisen päamäärän saamiseksi on kyettävä rajaamaan epäoleelliset tavoitteet pois. Oleellisuuksien ja odotusten ristiriidoissa voi kokea persoonallisuuden eheytymistä, itsetunnon voimistumista - mutta entä maailma oman eheyden ulkopuolella. Laadullisten arvojen jatkuva korostuminen taidekasvatuksellisen toiminnan johtavana ajatuksena ei voi olla vaikuttamatta ajattelutapaan yleisimminkin.

Taidekasvatuksen tehtävä ei ole olla tauko tiedon keskellä. Taidekasvatus tarjoaa mitä suurimmiassa määrin tietoa. Mutta se on voitava tehdä tajdekasvatukselle ominaisella tavalla - laadullisia arvoja painottaen. Tällaisenä taidekasvatuksesta misodostuu muuta kasvatustoimintaa täydentävää - olemisen moninaisuutta rikastavaa. Taidekasvatus on yhä olemassa oleva mahdollisuus - vaan mikä saisi käärmeen pysymään paratiisissa.

Taidekasvatuksen mahdollista merkitystä arvioitaessa on syytä huomata ilmaisullisen prosessin ja tietokonejärjestelmän yhtäläisyyksiä — vaihtoehtoja on simultaanisesti tuotettavissa runsaasti. Humaanin päätöksen voi tehdä ihminen. Mitä arvoja korostaen valinta tapahtuu? Isossa mutta vähäväkisessä maassa laadullisten arvojen laajaalaisen merkityksen tajuaminen ei liene vähäinen etu. 